\title{
Recurrent Bilateral Orbital Infiltration as Primary Manifestation of Rosai Dorfman Disease
}

\author{
Belinda Pustina1 ${ }^{1}$, Naser Salihu ${ }^{1}$, Arben Rroji ${ }^{2}$, Gentian Kaloshi' ${ }^{2}$, Mentor Petrela ${ }^{2}$ \\ ${ }^{1}$ Department of Ophthalmology, University Clinical Center of Kosovo, Prishtina, Kosovo \\ ${ }^{2}$ Department of Neurosurgery, University Hospital Center “Mother Theresa”, Tirana, Albania \\ Email: belindapustina@gmail.com
}

How to cite this paper: Pustina, B., Salihu, N., Rroji, A., Kaloshi, G. and Petrela, M. (2017) Recurrent Bilateral Orbital Infiltration as Primary Manifestation of Rosai Dorfman Disease. Open Journal of Ophthalmology, 7, 225-229.

https://doi.org/10.4236/ojoph.2017.73030

Received: August 10, 2017

Accepted: August 27, 2017

Published: August 30, 2017

Copyright (c) 2017 by authors and Scientific Research Publishing Inc. This work is licensed under the Creative Commons Attribution International License (CC BY 4.0).

http://creativecommons.org/licenses/by/4.0/

\begin{abstract}
Rosai Dorfman disease, also known as histiocytosis with massive lymphadenopathy, is a very rare idiopathic disease. It is characterized by over production and accumulation of non Langerhans sinus histiocyte most often in lymph nodes, but may occur in other areas leading to organ damage. Based on the research, it can be caused by an infectious agent, immunodeficiency or autoimmunity and genetic causes. Extranodal manifestation is uncommon, however extranodal sites include liver, kidney, respiratory organs, orbit and eyeball. We present a case report of a 44-year-old female with recurrent bilateral orbital infiltration as first location of Rosai Dorfman disease.
\end{abstract}

\section{Keywords}

Extranodal Rosai Dorfman, Genetic, Immunodeficiency, Histiocytosis with Massive Lymphadenopathy, Orbit, Kidney

\section{Introduction}

Rosai Dorfman disease is an uncommon histiocytic disorder first described by Rosai and Dorfman in 1969 as sinus histiocytosis with massive lymphadenopathy [1]. The disease is usually chronic with spontaneous remission and is refractory to treatment [2]. Rosai-Dorfman does not usually threaten life or organ function. It is believed that $5 \%$ to $10 \%$ of patients have progressive disease that may damage tissue. However, for most patients, the disease is self-limited, and the outcome is good. Diagnosis of Rosai Dorfman disease is done by histopathologic tests. Langerhans cell histiocytosis, Reticulohistiocytoma and Juvenile xanthogranuloma are listed in differential diagnosis [3] [4]. Based on the literature there are no large studies performed and many of the patients do not require 
treatment. There are other diseases that can be manifested with histiocytosis and should not be misdiagnose with Rosai Dorfman disease. Juvenile xanthogranuloma, reticulohistiocytoma and langerhans cell histiocytosis are some of them [5]. In Rosai Dorfman disease CD68 and S100 are positive, and CD1A is negative. In order to set proper diagnosis we have to exclude these immunohistochemical tests in other diseases.

Characteristic "ground cell" cytoplasm is seen in reticulohistiocytoma and "touton" giant cells with lipidisation of hystiocytes in juvenile xanthogranuloma. These other diseases should not display emperipolesis [6]. Rosai Dorfman disease in kidneys is very rare and as differential diagnosis we should exclude malignant fibrous histiocytomas, leukemia, lymphoma, tuberculosis or renal carcinoma [7] [8].

\section{Case Report}

A 45-year-old female was referred to our clinic with signs of pansinusitis, pain in the right orbit and diplopic vision when she turned the eyes to the right position. In the $\mathrm{CT}$ of the head orbital lesion was noticed (Figure 1).

After the surgery was performed a capsulated non hemorrhagic lesion with hard consistence was removed. Surgery resolved above symptoms and no complication was observed. After 4 months' regression of the clinical signs with pain appeared in the left eye, she also had proptosis and blurred vision. MRI findings showed lesion in left orbit and left cavernous sinusitis, also frontal lesion. It was suspected for lymphoma in differential diagnosis. Laboratory examinations revealed: RBC $3.65 \times 10^{6} / \mathrm{mm}^{3}$ HGB $10.6 \mathrm{~g} / \mathrm{dL}$, HCT 34.5 . The second surgery was performed in left orbit (Figure 2).

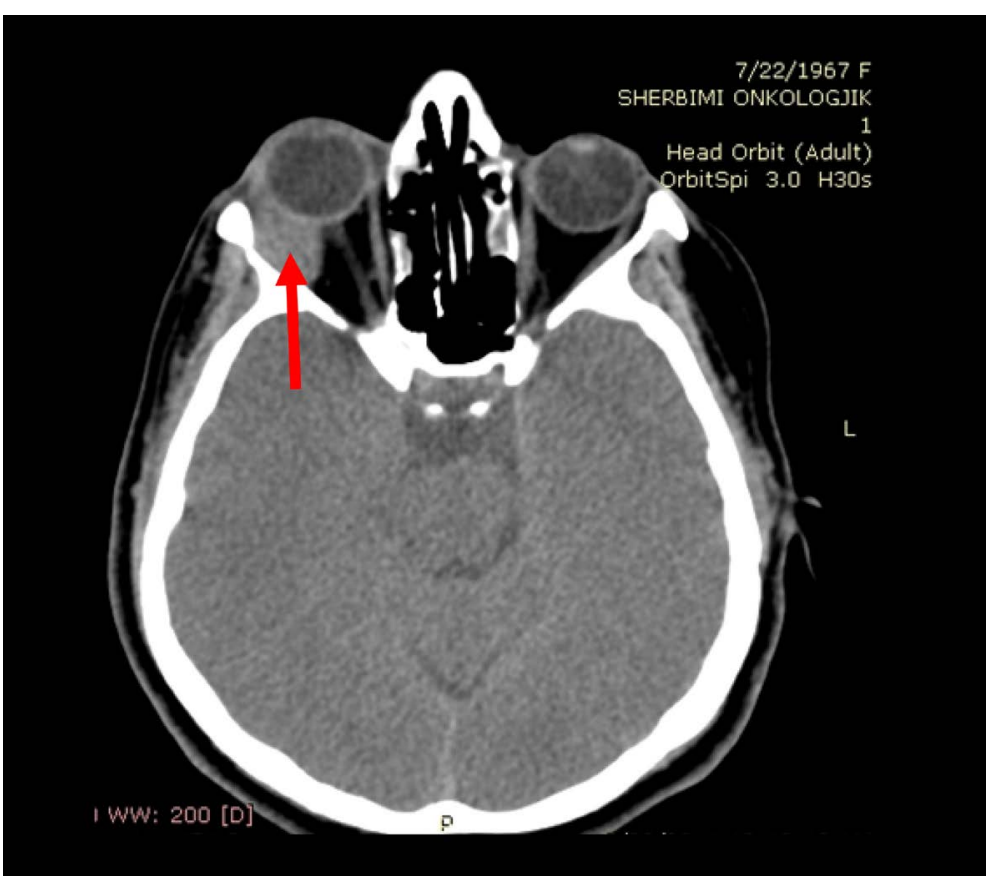

Figure 1. CT scan showing an isodense lesion at lateral part of right orbit. 


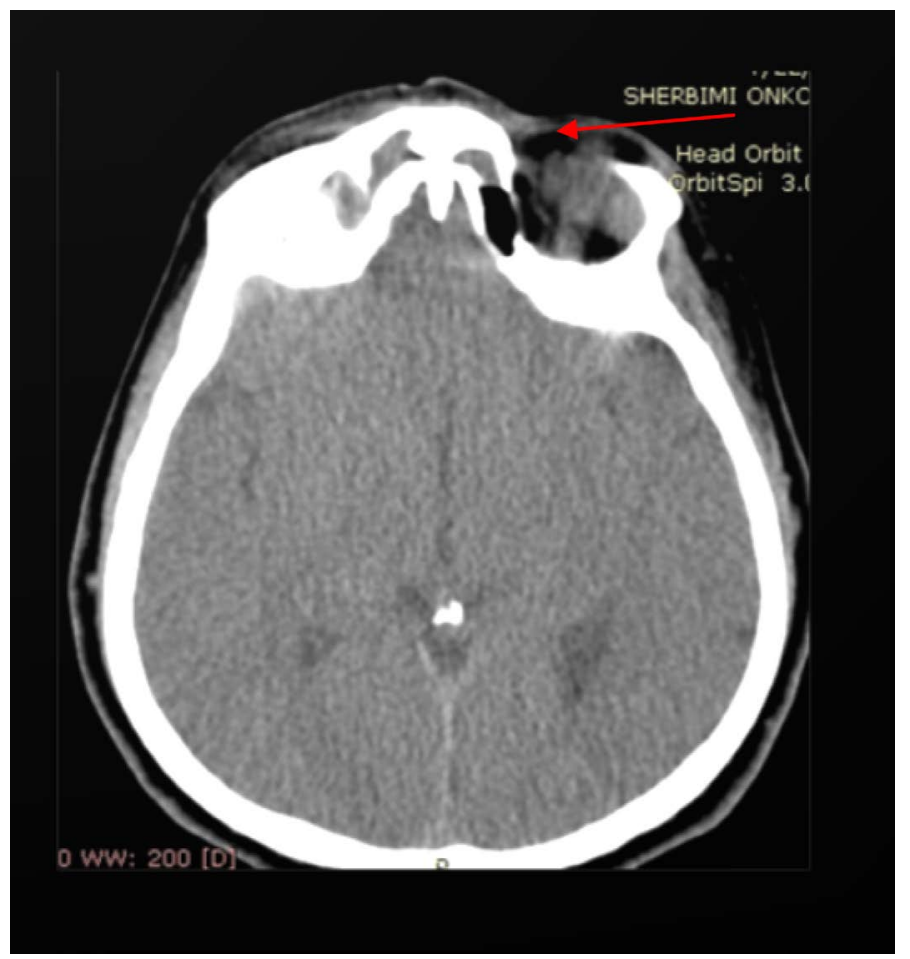

Figure 2. CT scan after the left orbital tumor removed.

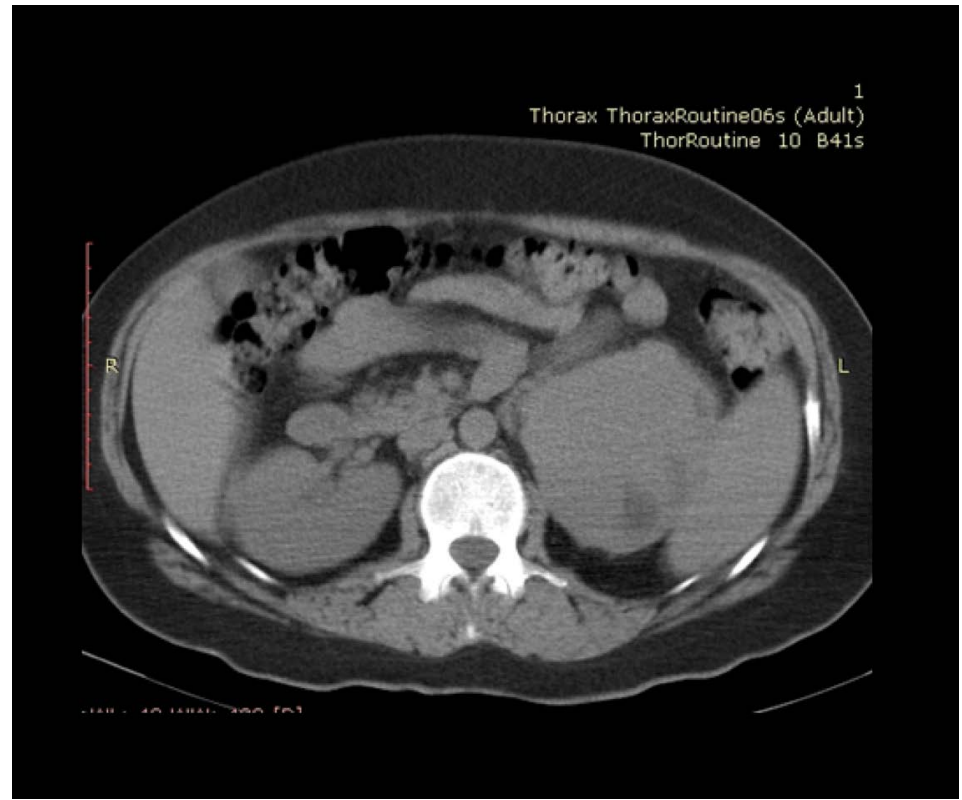

Figure 3. Extraorbital lesion in left kidney.

Capsulated, hard mass was removed. Second biopsy was done and in the conclusion it resulted with non specific granular inflammation. Immunohistochemistry (IHC) was positive for CD68+, S100+, CD38+ in plasmatic cells, CD 45, CD5, CD3 stained mature lymphocytes and negative for HMB 45-. As a conclusion the diagnosis was extranodular Rosai Dorfman Disease. After two years proptosis in both eyes was noticed with the recurrence of the disease in both orbits. Total removal of the tumor was done by surgery in both orbits. This time 


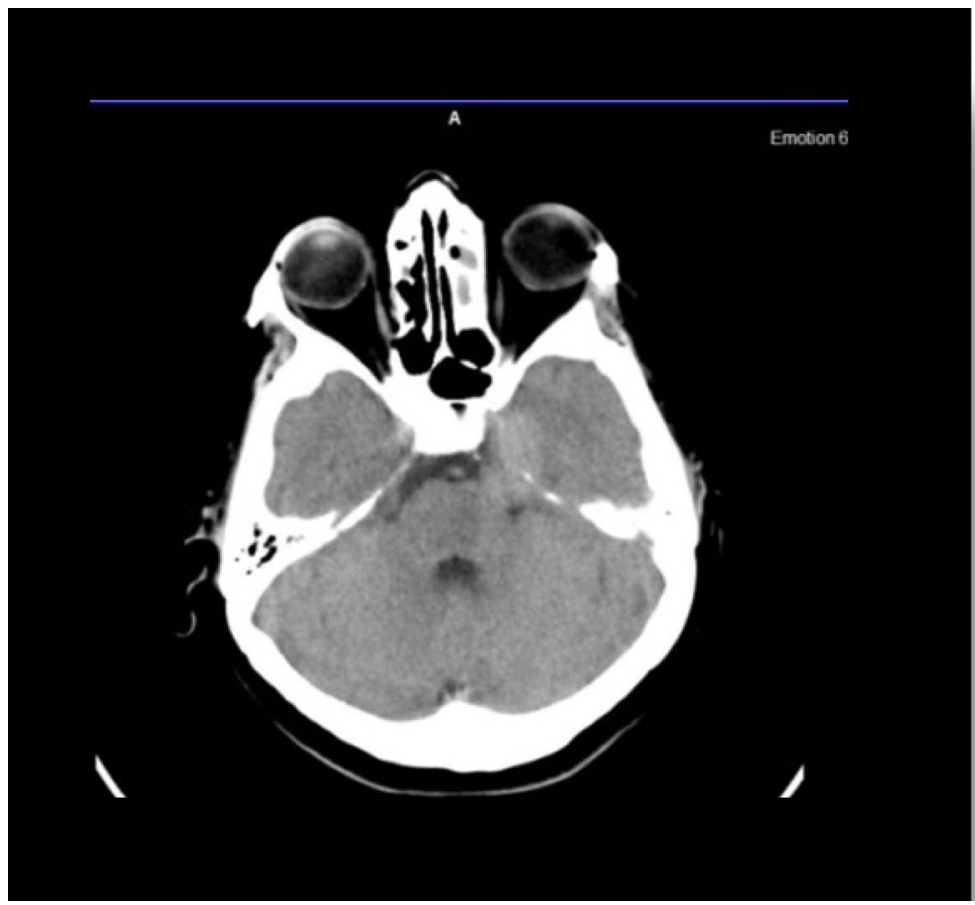

Figure 4. Orbits after surgery and medical treatment.

patient had symptoms of pain in kidney and laboratory examination revealed high urea [Urea $=52.2 \mathrm{~g} / 24$ hours]. Immediately the kidney CT was performed and it resulted with infiltrative renal mass in the left kidney (Figure 3).

She was treated with corticosteroids and oral methotrexate. The follow up CT resulted negative for recurrence and total disappearing of the lesion from the orbits and head (Figure 4).

\section{Conclusion}

Extranodal orbital Rosai Dorfman disease is a very rare condition. Furthermore, bilateral orbital infiltration as first sign of the disease as in our case is even rarer. For that reason, this case should raise the awareness among ophthalmologists and it should be considered in differential diagnosis for orbital tumors.

\section{References}

[1] Rosai, J. and Dorfman, R.F. (1969) Sinus Histiocytosis with Massive Lymphadenopathy: A Newly Recognized Benign Clinicopathological Entity. Archives of Pathology, 87, 63-70.

[2] Wu, S.Y., Ma, L. and Tsai, Y.J. (2004) Partial Removal of Orbital Tumor in Rosai-Dorfman Disease. Japanese Journal of Ophthalmology, 48, 154-157.

[3] Brenn, T., Calonje, E., Granter, S.R., Leonard, N., Grayson, W., Fletcher, C.D.M., et al. (2002) Cutaneous Rosai-Dorfman Disease Is a Distinct Clinical Entity. American Journal of Dermatopathology, 24, 385-391.

https://doi.org/10.1097/00000372-200210000-00001

[4] Kuo, T.T., Chen, T.C., Lee, L.Y. and Lu, P.H. (2009) IgG4-Positive Plasma Cells in Cutaneous Rosai-Dorfman Disease: An Additional Immunohistochemical Feature and Possible Relationship to IgG4-Related Sclerosing Disease. Journal of Cutaneous 
Pathology, 36, 1069-1073. https://doi.org/10.1111/j.1600-0560.2008.01222.x

[5] Brenn, T., Calonje, E., Granter, S.R., Leonard, N., Grayson, W., Fletcher, C.D.M., et al. (2002) Cutaneous Rosai-Dorfman Disease Is a Distinct Clinical Entity. American Journal of Dermatopathology, 24, 385-391. https://doi.org/10.1097/00000372-200210000-00001

[6] Kuo, T.T., Chen, T.C., Lee, L.Y. and Lu, P.H. (2009) IgG4-Positive Plasma Cells in Cutaneous Rosai-Dorfman Disease: An Additional Immunohistochemical Feature and Possible Relationship to IgG4-Related Sclerosing Disease. Journal of Cutaneous Pathology, 36, 1069-1073. https://doi.org/10.1111/j.1600-0560.2008.01222.x

[7] Weiss, S.W., Goldblum, J.R. and Enzinger, F.M. (2001) Enziinger and Weiss Soft Tissue Tumors. 4nd Edition, Mosby, St. Louis, MO, p. 1622.

[8] Rodriguez-Galindo, C., Helton, K.J., Sánchez, N., Rieman, M., Jeng, M. and Wang, W. (2004) Extra Nodal Rosai-Dorfman Disease in Children. Journal of Pediatric Hematology/Oncology, 26, 19-24.

https://doi.org/10.1097/00043426-200401000-00007

Submit or recommend next manuscript to SCIRP and we will provide best service for you:

Accepting pre-submission inquiries through Email, Facebook, LinkedIn, Twitter, etc. A wide selection of journals (inclusive of 9 subjects, more than 200 journals)

Providing 24-hour high-quality service

User-friendly online submission system

Fair and swift peer-review system

Efficient typesetting and proofreading procedure

Display of the result of downloads and visits, as well as the number of cited articles

Maximum dissemination of your research work

Submit your manuscript at: http://papersubmission.scirp.org/

Or contact ojoph@scirp.org 